\title{
Frontier mystery: An unusual mound of kopi mourning caps on the eastern edge of the Simpson Desert
}

\author{
Giles Hamma, ${ }^{\mathrm{a}, \mathrm{b}}$ Don Rowlands ${ }^{\mathrm{c}}$ and Mike Smith ${ }^{\mathrm{d}, \mathrm{e}, *}$ \\ ${ }^{\text {a }}$ Archaeological Risk Assessment Services, PO Box 67, Katoomba, NSW 2780, Australia; ${ }^{\text {b }}$ South Australian Museum, \\ North Terrace, Adelaide, SA 5000, Australia; ${ }^{\text {c }}$ Queensland Parks and Wildlife Service, Birdsville, QLD 4482, \\ Australia; ${ }^{\mathrm{d}}$ College of Humanities, Arts and Social Sciences, Flinders University, GPO Box 2100, Adelaide, SA 5001,

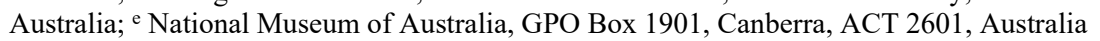 \\ * Corresponding author mike.smith@nma.gov.au
}

\begin{abstract}
On the eastern edge of the Simpson dune field, an unusual find of 40-60 mourning caps in a single cluster, prompts us to raise issues about its interpretation. This region is known for violence along the colonial frontier, and this kopi site is only one to two days walk from the site of a known massacre of a ceremonial gathering of people at Kaliduwarry waterhole in about 1878 . There is no direct evidence showing that this site coincides with colonial expansion in this region in the late 1870s, but the condition of these caps and their geomorphic context indicate that this site cannot be older than a few hundred years. If it dates to the pre-contact period in the 1800 s, this kopi site must reflect a higher degree of social ranking and complexity than is usually assumed in the ethnography. Whether or not this remarkable site relates to the death of a single, high-ranked individual or multiple deaths on the colonial frontier in a single event, this cluster of mourning caps indicates that 40-60 people were in mourning simultaneously.
\end{abstract}

\section{Introduction}

Archaeological evidence for frontier conflict is often ambiguous. Without oral history of an event, or direct examination of skeletal remains, the material evidence often allows more than one interpretation. On the eastern edge of the Simpson dune field, an unusual find of 40-60 mourning caps, in a single cluster, highlights some of the issues (Figure 1). This site may represent an archaeological record of violence along the Eyre Creek-Mulligan River pastoral frontier sometime between 1870 and 1900. Alternatively, it may record a higher degree of social hierarchy in pre-contact groups than usually recorded for ethnographic societies in the Australian arid zone.

\section{Regional context}

The eastern edge of the vast Simpson dune field is bounded by a series of rivers, creeks and swamps, including the Georgina River, Mulligan River, Eyre Creek, and the massive Diamantina-Goyder Lagoon-Warburton River system (Purdie 1984). This network of ephemeral rivers, permanent waterholes, and floodplains represented a natural frontier for pastoral expansion into this part of the arid zone between 1870-1900, and was a colonial fracture-zone known for periodic outbreaks of violence between cattlemen and Aboriginal groups. Attacks by pastoralists and native mounted police annihilated some groups (especially those along the lower part of Eyre Creek or around Goyder's Lagoon further to the south) and decimated others (such as Wangkangurru people drawn out of the dune field into pastoral districts, and other people drawn from farther afield to attend large ceremonial gatherings held periodically at the permanent waterholes in this area). Six major massacres are known from the Birdsville area (Hercus 1977, 1991:156; McLean and Hercus 1986). These typically involved punitive attacks on people gathered for ceremonies at local waterholes. Some of these attacks killed 200+ people (Hercus 1991:156). This background of violence is relevant to any assessment of the large number of mourning caps recorded here, as this kopi cap site is only one or two days walk from Kaliduwarry waterhole, the location of a massacre in about 1878 .

\section{Kopi mourning caps}

Mourning caps - colloquially known as 'widows caps' - were skull caps made of gypsum plaster (kopi) or pipe clay. They were widely used across the Murray-Darling basin and Lake Eyre region as part of mourning rituals following the death of a husband, relative or classificatory kin (Davidson 1949; Elkin 1938; Etheridge 1899; Goddard 1936; Horne and Aiston 1924; Roth 1907).

\section{Manufacture}

Kopi or kopai was a plaster made of burnt gypsum, which was crushed and mixed with water to form a paste. This material was widely used in mortuary rituals as body paint, as a paste applied to the hair, and for mourning caps. The latter were plaster basins, or skull caps, (17-20 cm in diameter) covering the head and were built up by repeated applications of plaster until they were $\sim 25 \mathrm{~mm}$ thick (often thicker towards the crown in the more elaborate 'helmet' form). They were often built up over a hair-net on a cropped scalp, but the Wangkangurru are recorded as applying plaster directly to the head (Davidson 1949:60; Horne and Aiston 1924:153-156, Figure 89).

\section{Use}

The ethnography shows that kopi skull caps were predominately used by women, whereas other forms of kopi used in mortuary ritual (such as body paint, hair ornaments, kopi balls, or dummy caps) were used by either sex (Davidson 1949). Elaborate caps were worn by widows over a mourning period lasting several weeks. Davidson (1949:61) suggests that, amongst neighbouring Diyarie people, they were also worn by male and female members of the opposite moiety to the deceased. 


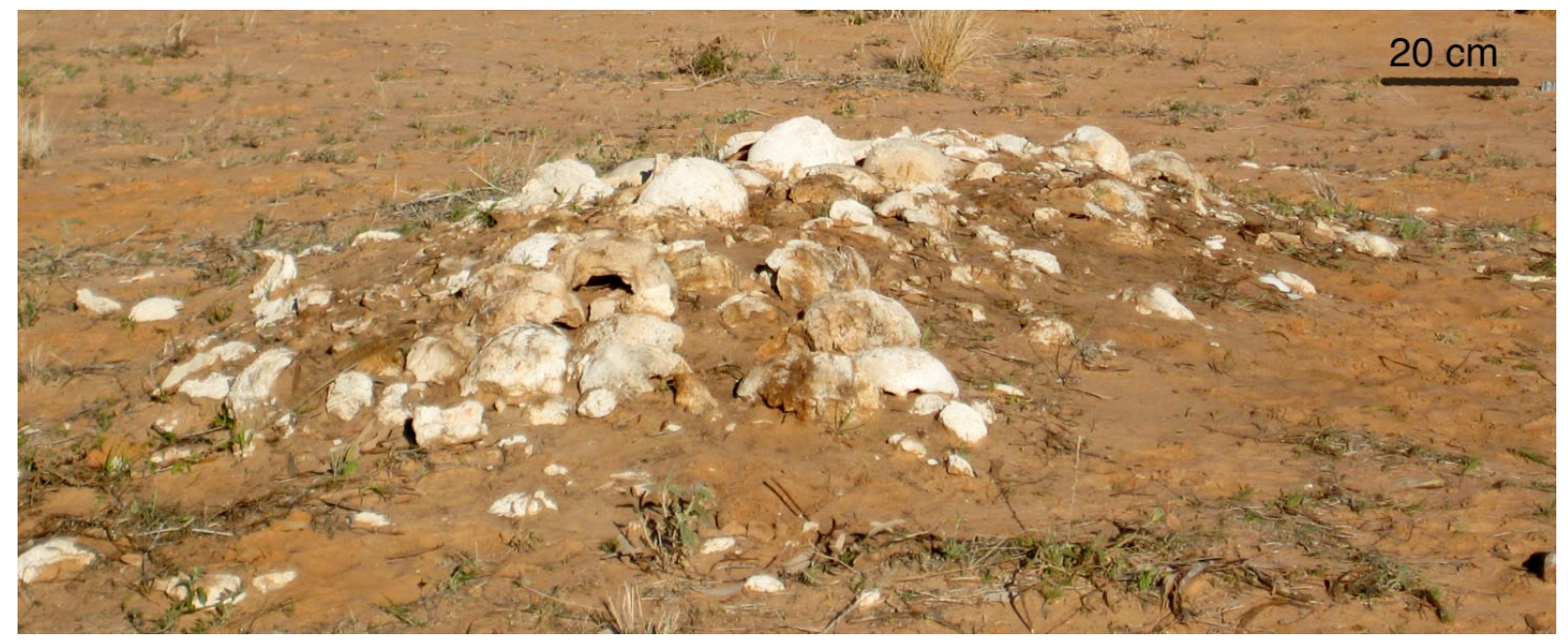

Figure 1. Mound of kopi caps, Mulligan River area, southwest Queensland. Scale bar $20 \mathrm{~cm}$.

\section{Discard}

After the prescribed mourning period, kopi caps were removed and placed on a grave, or discarded wherever they were removed. In some cases, a cap could be removed moreor-less intact. In other cases, it would have to be broken during removal and cut free from the hair. In the Lake Eyre region, these artefacts most often occur as solitary caps discarded in a range of locations, including but not invariably on graves. The disposal of a large number of caps (40-60 caps) in a single location - whether or not on a grave - is unusual; in this region, it is unique. The only comparison is a grave in the upper Darling region, where Goddard (1936) reports 70 caps on the grave of a woman. However, this site differs from the Mulligan River site in several ways. First, all the caps on Goddard's site are pierced by an object. Secondly, they were arranged in a conical mound $90 \mathrm{~cm}$ tall. Thirdly, many were too small to have been used (Goddard 1936). In a comprehensive review of kopi mourning caps, Davidson (1949:63-64), classified these small kopi objects as 'dummy' caps used as emblems of mourning.

\section{The Site}

This cluster of mourning caps was first discovered in December 2006 by a stockman, and identified as a possible grave by local Wangkangurru men. The site was then visited independently by two archaeological parties. GH recorded the site in 2007, as a consultant preparing a report for the Wangkangurru traditional owners, and for Adria Downs pastoral station (Hamm 2007). MAS visited the site with an Australian Desert Expeditions (ADE) camel team in 2008, as part of a program of scientific surveys in this part of the dune field. Both visits were under the direction of DR. In each case, the site was gridded and a site plan drawn (Figure 2), and it was photographed to allow assembly of a digital photomosaic (Figure 3).

The site is on a longitudinal dune on the bank of the Mulligan River about one or two days walk from Kaliduwarry waterhole. The kopi caps rest on a low, diffuse ridge of sand, that forms a spur on the flank of this dune, with an erosion gully on one side. This feature was initially interpreted as a grave because of the presence of an apparent mound ( $4 \mathrm{~m} \mathrm{x}$ $2 \mathrm{~m} \times 30 \mathrm{~cm}$ high) (Figure 1) and the presence of mourning caps. This could not be confirmed as no human bone or grave- pit was visible, and as none of the clayey substrate appeared to have been disturbed.

All of the caps are broken, although many represent substantial pieces. Many fragments could be readily reassembled to form entire caps. We estimated that 40-60 complete basin-shaped skull caps are represented. All appeared to be of similar age and condition. There was no evidence for phased or sequential accumulation of the caps.

We found no evidence for significant weathering, external fracturing, or burnt surfaces, which indicates that breakage of the caps most likely occurred during their removal, rather than by post-depositional processes. Approximately $10+$ fragments of mussel shell (Velesunio sp.) are interspersed within the cluster of caps, and were perhaps used during removal of the mourning caps to cut away any trapped hair.

Measurement of 12 caps shows these range between $18-20 \mathrm{~cm}$ in diameter and $28-52 \mathrm{~mm}$ in thickness. This indicates that all are from adults, and that these kopi caps are towards the extreme end of recorded thickness, consistent with the elaborate mourning caps used by women. No residual strands of hair appeared to be embedded in the kopi. Nor were there any impressions of hair-nets. We have not identified the nearest source of gypsum for production of kopi plaster. However, as gypsum outcrops in several places along the banks of Mulligan River, there may be a local source.

No contact period artefacts were present in the vicinity of this kopi site. There is therefore no direct evidence that it coincides with colonial activity in this region. However, the condition and context of these fragile artefacts indicates that this is a relatively young site, dating within the last few hundred years (Figure 4). Nor can we rule out the alternative possibility that it dates to the immediate pre-contact period in the $1800 \mathrm{~s}$. However, the site cannot be of much greater antiquity as it lies on unconsolidated dune sand, in a geomorphically active area, and because the kopi caps, which are relatively fragile objects, are unweathered and near-entire. We noted a low density of late Holocene stone artefacts $\left(1 / 1000 \mathrm{~m}^{2}\right.$, a total of 160 stone artefacts) including tula adze slugs, fragments of grindstones, unmodified flaked stone, and amorphous retouched pieces in the area surrounding the mound. These represent the usual surface float of artefacts expected near a waterhole. From our observations, none of this material need have any direct association with the kopi cap site. 

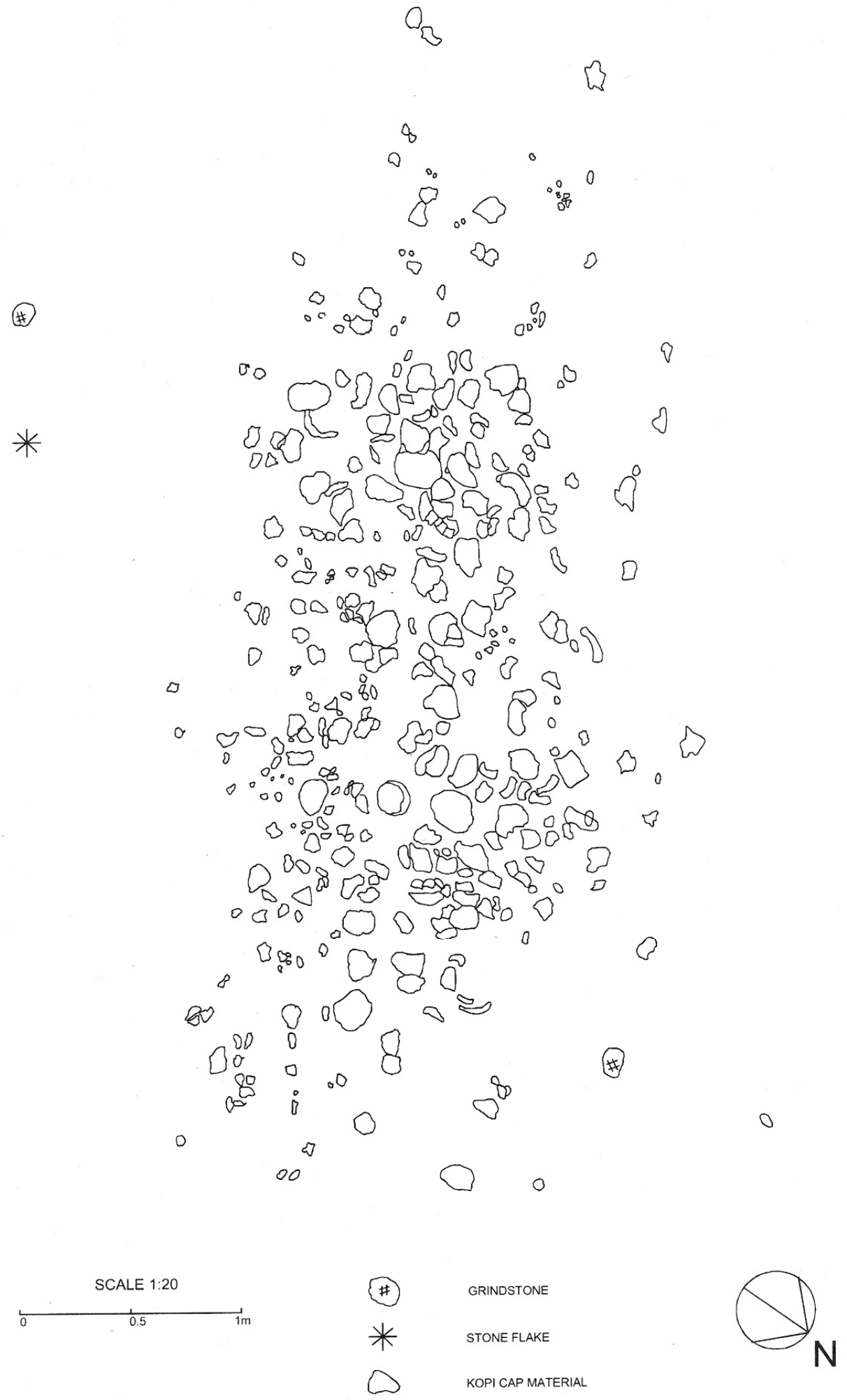

Figure 2. Map of the kopi site. 


\section{Interpretation}

The archaeological evidence indicates that $40-60$ people were in mourning simultaneously. The size and morphology of these kopi caps (basin-shaped skull caps) suggests that the mourners were adult women, using caps without hair-nets, as was the Wangkangurru practice. This kopi site is relatively young, probably dating within the contact period or immediately before it. Whether or not this site centres on a grave, it appears that a large number of women went into mourning after a single event. At the conclusion of the mourning period, these women were coresident at a local waterhole. When they removed their caps, they placed them in the same location, on a low rise, possibly but not conclusively on a grave.

\section{Discussion}

Without examination of the putative burial, an oral history relating to this event, or a better estimate of its age, it is not possible to decide which of several hypotheses best explains this site.

\section{Hypothesis 1}

In hypothesis 1 we assume that these mourning caps are associated with the grave of an individual, and that the mourning was in response to his or her death. If all, or most, of the mourners were this individual's widows, it implies a level of polygyny not otherwise recorded for desert societies, where men generally had one to three wives. Alternatively, if the mourners comprised a wider set of men and women, then such a large number of mourners implies that they were drawn from more than one local descent group, possibly representing $10 \%$ of a community. In either case, this kopi site would reflect a higher degree of pre-contact social ranking and complexity than is usually assumed in the ethnography. There is some evidence in support of this. For instance, various writers note the existence of substantial seasonal villages in this region (Davis 2002:130; Sturt 1849:figure facing page 254; Wallis et al. 2017). There was also a high degree of gerontocratic privilege and monopolisation of women, together with a well-developed system of community and ritual leadership (Horne and Aiston 1924; Howitt 1904; Smith 2013:297-300). Against this hypothesis, we note that kopi sites with such a large number of caps are rare or unique in the archaeological record in this region, and are not the usual systemic product of these societies.

\section{Hypothesis 2}

In this second hypothesis, we assume that there is a causal link between the killings at nearby Kaliduwarry waterhole in about 1878 and this cluster of mourning caps. This hypothesis assumes that few, if any, of the kopi caps are directly associated with an individual grave and that a large number of women went into mourning as a result of this massacre. It also assumes that these women were still in the area at the close of the mourning period, and that they chose to remove their kopi caps and place them in a common location, possibly on an existing grave. Some combination of these hypotheses is also possible, if for instance, a high-ranking individual died as a result of the attack on a ceremonial gathering at Kaliduwarry, and was interred at this kopi site. Whatever the case, this poignant site warrants some record in the archaeological literature.

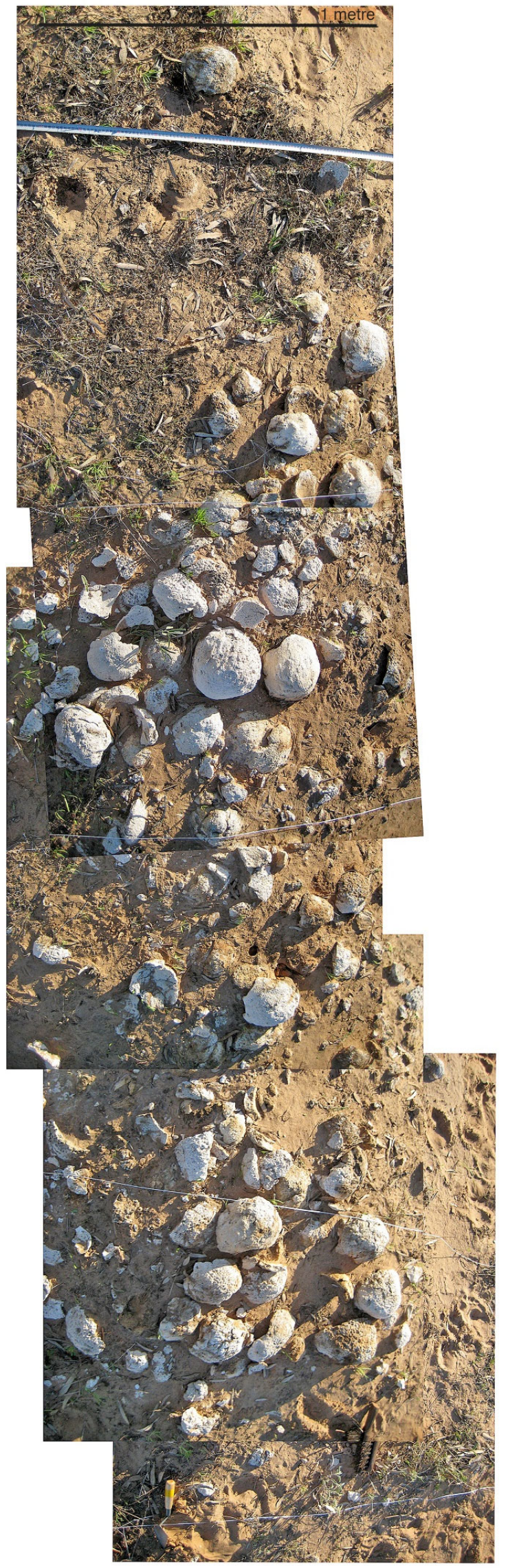

Figure 3. Photomosaic showing the distribution of kopi caps. Scale bar is $1 \mathrm{~m}$. 


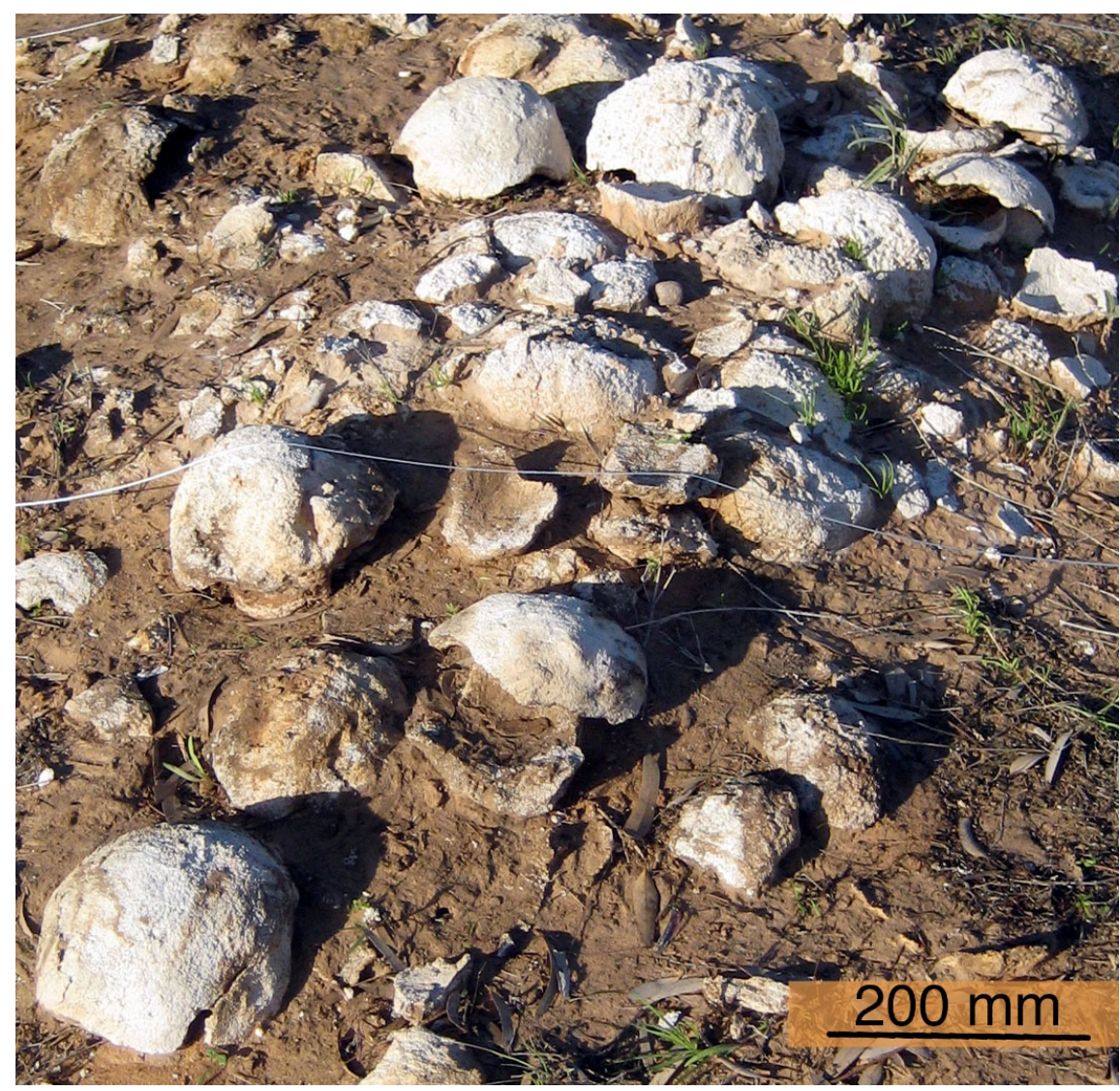

Figure 4. Detailed view of the kopi caps. Scale bar $200 \mathrm{~mm}$.

\section{Acknowledgements}

GH thanks Don Rowlands and Jimmy Crombie for their advice and permission to carry out this work. MAS thanks Australian Desert Expeditions, Andrew Harper and Don Rowlands for the opportunity to visit this site. All the authors thank Adria Downs pastoral station for their cooperation.

Davis, R.C. (ed.) 2002 The Central Australian Expedition, 18441846: The Journals of Charles Sturt. London: The Hakluyt Society.

Davidson, D.S. 1949 Mourning-caps of the Australian Aborigines. Proceedings of the American Philosophical Society 93(1):57-70.

Elkin, A.P. 1938 The Australian Aborigines. Sydney: Angus \& Robertson. Aborigines. Proceedings of the Linnean Society of New South Wales 24(95):333-345. https://doi.org/10.5962/bhl.part.7669 27. https://doi.org/10.1111/j.1835-9310.1936.tb00925.x

Hamm, G. 2007 A Preliminary Archaeological Investigation of a Rare Burial Site in the North-East Simpson Desert, Queensland. Unpublished report to Wangkangurru traditional owners, Desert Channels Queensland, and Adria Downs Pastoral Station.

Hercus, L.A. 1977 Tales of Nadu-Dagali (Rib-Bone Billy). Aboriginal History 1:53-76. https://doi.org/10.22459/AH.01. $\underline{2011.03}$

Hercus, L.A. 1991 Glimpses of the Karanguru. Records of the South Australian Museum 25:139-159.

Horne, G. and G. Aiston 1924 Savage Life in Central Australia. London: Macmillan.

\section{References}

Etheridge, R. Jr 1899 The "widow's cap" of the Australian

Goddard, R.H. 1936 Kopi: Funerary skull caps. Mankind 2(2):25-

Howitt, A.W. 1904 The Native Tribes of South-East Australia. London: Macmillan.

McLean, M. and L.A. Hercus 1986 The end of the Mindiri people. In L.A. Hercus and P. Sutton (eds), This is What Happened: Historical Narratives by Aborigines, pp.183-192. Canberra: Australian Institute of Aboriginal Studies.

Purdie, R. 1984 Land Systems of the Simpson Desert Region. Natural Resources Series 2. Melbourne: Division of Water and Land Resources, Commonwealth Scientific and Industrial Research Organization.

Roth, W.E. 1907 North Queensland Ethnography. Bulletin No. 9: Burial ceremonies, and disposal of the dead. Records of the Australian Museum 6(5):365-403. https://doi.org/10.3853/j.00671975.6.1907.1021

Smith, M. 2013 The Archaeology of Australia's Deserts. Cambridge: Cambridge University Press.

Sturt, C. 1849 Narrative of an Expedition into Central Australia. London: Boone.

Wallis, L.A., I. Davidson, H. Burke, S. Mitchell, B. Barker, E. Hatte, N. Cole and K.M. Lowe 2017 Aboriginal stone huts along the Georgina River, southwest Queensland. Queensland Archaeological Research 20:1-8. https://doi.org/10.25120/qar.20.2017.3584

Citation: Hamm, G., D. Rowland and M. Smith 2019 Frontier mystery: An unusual mound of kopi mourning caps on the eastern edge of the Simpson Desert. Queensland Archaeological Research 22:59-63. https://doi.org/10.25120/qar.22.2019.3700

https://doi.org/10.25120/qar.22.2019.3700 